\section{ECONOMICS}

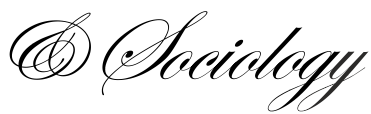

\title{
DOES CORPORATE TAX AVOIDANCE EXPLAIN CASH HOLDINGS? THE CASE OF VIETNAM
}

\author{
Nguyen Vinh Khuong, \\ University of Economics and Law, \\ VNU-HCM, \\ Ho Chi Minh City, Vietnam, \\ E-mail:kbuongnv@uel.edu.vn \\ Nguyen Tran Thai Ha, \\ Saigon University, \\ Ho Chi Minh City, Vietnam, \\ E-mail: \\ nguyen.tranthaiha@sgu.edu.vn
}

\author{
Mai Thi Hoang Minh, \\ University of Economics $\mathrm{Ho} \mathrm{Cbi}$ \\ Minh City, \\ Ho Chi Minh City, Vietnam, \\ E-mail:bminb@ueh.edu.vn
}

\section{Phung Anh Thu, \\ Nguyen Tat Thanh University, \\ Ho Chi Minb City, Vietnam \\ E-mail:pathu@ntt.edu.vn \\ *Corresponding Author}

Received: December, 2018

1st Revision: April, 2019

Accepted: May, 2019

DOI: $10.14254 / 2071-$

789X.2019/12-2/5

JEL Classification: G32, H35

\begin{abstract}
Recent tax evasion research has considered tax avoidance as an act of minimizing the amount of taxes to be paid through appropriate methods. This research aims to investigate the impact of corporate tax avoidance on the corporate cash holdings of the firms listed at Vietnam's stock market. The sample consists of 125 non-financial firms' data as of 2010-2016, with the total of 875 observations. The investigation utilizes three different tax avoidance measures to examine the robustness of the research results. We used GMM estimator to test our hypotheses. This research ascertains empirical evidence that tax avoidance has a significant positive relationship with cash holdings of listed firms in Vietnam. Three measurements of tax avoidance presented the same conclusions to the regression results.
\end{abstract}

Keywords: corporate tax avoidance, corporate cash holdings, corporate effective tax rates, book-tax difference, Vietnam

\section{Introduction}

Corporate tax contributes to development economics because this is one of the key to social responsibility. Firms gain profit and then they reduce net income before taxes. According to OECD (2013), firms often want to avoid their responsibility of tax payments. This may have a wide range of negative consequences for the whole economy and society as well. 
At the same time, corporate tax avoidance enhances shareholder benefit. This makes corporate tax avoidance a significant corporate strategy (Armstrong, Blouin, Jagolinzer \& Larcker, 2015; Mihir A Desai \& Dharmapala, 2009; Hanlon \& Heitzman, 2010; Wilson, 2009). This research indicates there is a positive relationship between corporate tax avoidance and firm value. Income tax expense is directly related to profit. That is the reason why managers try to minimize it to enhance firm's value. Hanlon, Kelley Laplante, and Shevlin (2005), Ayers, Jiang, and Laplante (2009) have found that reduction of income tax expenses has direct relation with corporate tax avoidance. Their research discusses two aspects of corporate tax avoidance - the transferred benefit from government to third parties and the agency cost between managers and third parties.

Our research examines the factors effect on tax avoidance in a developing market context. Particularly, agency conflicts and earning management are very important in Vietnam context as it was already mentioned in previous studies (Hai \& Nunoi, 2008; Hoang, Abeysekera \& Ma, 2017; Nguyen \& Van Dijk, 2012). Therefore, our research determines both positive or negative effects of corporate tax avoidance and cash holdings for Vietnam market.

This investigation contributes to literature on tax avoidance in the following ways. Firstly, previous investigations on the relation between corporate tax avoidance and cash holdings only measured corporate tax avoidance through corporate effective tax rates (Di \& Hanke, 2013; Kurniawan \& Nuryanah, 2017; Wang, 2015). Therefore, this study measures all three aspects of corporate tax avoidance to assure the sustainability of our research results. Secondly, emerging markets have relatively little researched in this regard (Kurniawan \& Nuryanah, 2017; Wang, 2015). Additionally, there have been no studies on corporate tax avoidance and cash holdings in Vietnam in particular, to the best of our knowledge. Therefore, we see this research on Vietnam as necessary. Thirdly, we use the dynamic GMM method to analyze data, which improves the sustainability of the analytical results as compared to the previously used methods (FEM and REM) (Kurniawan \& Nuryanah, 2017). We have chosen GMM to solve the potential endogeneity problem. In the developing market context, there should be some control variables such as financial leverage, firm growth, firm size, cash flows from operating activities, and fixed assets.

Our research contributes to the agency cost literature on corporate tax avoidance in Vietnamese context. Our sample consists of 125 listed firms which disclose financial reporting and have audit reports covering the period from 2010 till 2016. Thus, our population is nearly 300 listed firms (the non-financial companies were listed before 2009). Moreover, we use three parameters (the annual cash effective tax rate, the long-run cash effective tax rate, and the permanent book-tax difference) to measures corporate tax avoidance. Their use has allowed us achieve our research goals.

The rest of the article proceeds as follows. Section 2 exhibits the literature and hypotheses. Sections 3 and 4 present the sample data and methodology. Section 5 describes the results of our empirical analysis and their discussion. Finally, we present the main conclusion, limitations of our research and a few recommendations for future research in the same direction.

\section{Literature Review}

\subsection{Agency theory and Trade-off theory}

The concept of tax avoidance is understood to be the legal application of tax mechanisms to reduce payable taxes within the framework of the law and the disclosure of important information to tax authorities. According to Mihir A. Desai and Dharmapala (2006) 
and Lisowsky (2010), avoiding taxes is part of the company strategy by using the shortcomings of tax laws and legal regulations to reduce the level of income tax payable. It can be done by requesting deductible and credit costs. One of the most common measures of tax avoidance is the effective tax rate. The effective tax rate is the ratio between the actual tax paid and income and it is often different from the nominal tax rate due to exemption, reduction or refund.

Although effective tax has been mentioned as one of the important factors that help determine the performance of businesses, however, efforts to reduce effective tax rates will benefit shareholders because of after-tax income. Increase; and, therefore, increase the bonus that shareholders receive from dividend payments. The agency theory was developed by Ross (1973), then this was developed by Jensen and Meckling (1976b), indicated that there is a conflict between manager and owner (shareholder) in risk division. Costs including these conflicts are referred to as an agency cost. Therefore, it can cause expensive in managing a company's tax rate. On the one hand, managers' efforts to reduce effective tax rates will benefit shareholders when maximizing their benefits. With the tax savings action, the tax burden is becoming smaller so that the company's net income becomes larger. Managers can also benefit from tax avoidance activities, which are a higher compensation or bonus because they are doing a good job of reducing the tax burden. On the other hand, due to information asymmetry, the owner did not have enough information to make the right decision and they did not solve tax related risks promptly. For example, if the government tax department finds that there is a future tax avoidance of the company, they will collect the previous tax and punish the company ((M. M. Frank, Lynch, \& Rego, 2009)). As a result, it will reduce income for shareholders, market value and increase ownership or agency costs ((Mihir A. Desai \& Dharmapala, 2006); (Dhaliwal, Huang, Moser, \& Pereira, 2011)) due to investors' negative perceptions. Finally, the company incurs other costs such as reputation costs and political costs (Hanlon and Slemrod 2009). Moreover, according to Mihir A. Desai and Dharmapala (2006), managers can hide asset purchases for hidden personal benefits in reducing effective tax rates. Managers can also pursue to achieve their own goals such as beautifying financial performance indicators transactions with privileged parties, or taking resources or assets of the company to meet personal interests ((S. Chen, Chen, Cheng, \& Shevlin, 2010)). Thus, according to S. Chen et al. (2010), tax avoidance is implemented by a company based on marginal benefits and marginal costs, including tax administration and tax avoidance.

\subsection{Tax avoidance and cash holdings}

The motive for holding cash, according to traditional theory, is considered from the marginal benefit and marginal cost of keeping money to maximize the wealth of shareholders (A. Dittmar, Mahrt-Smith, \& Servaes, 2003b). However, contrary to traditional theory, tax avoidance is an opportunistic act of managers to pursue personal interests in the context of agency theory. Evidence for this, starting with the research S. Chen et al. (2010), firms adjudicated to reduce the amount of tax they fund to the General Department of Taxation to maximize the benefits to managers and shareholders. The investigation explicated that the way to reduce tax payment to the General Department of Taxation. In detailed, companies had used techniques through algorithms to complex the transactions. This lead to users of financial information did not realize the nature of the economic transaction, and they did not interpret the business results of the business (S. Chen et al., 2010; Mihir A Desai \& Dharmapala, 2008).

Nevertheless, conflicts between managers and shareholders also have an influence on the incentive to reduce the amount of tax payable (S. Chen et al., 2010). Moreover, Y. Chen, Huang, Pereira, and Wang (2011) and J.-B. Kim, Li, and Zhang (2011) suggested that there is 
a positive relationship between corporate tax avoidance and firm opacity. In particular, these studies proved that managers want to reduce the tax burden by reducing the amount of tax paid to the state, which tended to hide information on financial statements (for example lower profit, lower revenue or higher cost). To explain this behavior, we used the agency theory and researches of Jensen and Meckling (1976a); Bushman and Smith (2001); Mihir A Desai and Dharmapala (2008) in the listed companies. These researchers demonstrated managers and shareholders often have different purposes, leading managers to take advantage of themselves and diminish the benefits of the shareholders in their company. In addition, firm opacity and asymmetry of information make the information in the transaction not reported widely to the shareholders to influence their decision-making.

Following Hanlon and Slemrod (2009) and J.-B. Kim et al. (2011), firms have avoided taxation which regularly encountered the problem in stock price because of concealing unfavorable information to shareholders. The hiding of the manager's information causes the board and shareholders did not catch timely information to make timely adjustments and decisions. Opler, Pinkowitz, Stulz, and Williamson (2001) demonstrated that managers constantly want to maximize their benefits, that the reason why they continuously consider investing or holding cash. This was obvious to say that cash was highly liquid, easily transferable (Myers \& Raghuram, 1998), therefore when the agency cost was increased, the managers tend to hold more cash in their firms. According to studies (A. Dittmar, MahrtSmith, \& Servaes, 2003a; Jensen, 1986), this behavior served their personal purpose.

In another aspect, Faulkender and Wang (2006); Dhaliwal et al. (2011) and Hogan and Noga (2012) argued that small firms had significantly simple taxation comparing large companies. Therefore, they did not expect tax evasion to have a negative impact on corporate cash holdings. Following M. Z. Frank and Goyal (2014), Di and Hanke (2013), they indicated there is a positive relationship between corporate tax avoidance and corporate cash holdings in bad times. Bad times in this research was considered by market-to-book ratio under $33 \%$ of the distribution of industry. They said that, during the bad times, small firms have corporate tax avoidance tend to hold more cash to shy away from the equity. However, Harford, Mansi, and Maxwell (2012) argued that when corporate tax avoidance occurs leading cash increase, managers favor using cash in other activities instead of keeping them for use in the future.

Because cash is one of the most liquid assets, an increase in cash can help managers escape from the suppliers' supervision, and implement investment and sponsorship behaviors that no shareholders' decision needed. Due to asymmetric information between agents and owners, it makes the company's assets transferred to agents. Thus, avoiding taxes gives managers more opportunistic behaviors and thus causes more harm to company owners instead of benefiting companies by increasing cash flow (Dhaliwal et al. (2011)). So we develop hypothesis relating to the relations corporate tax avoidance on cash holdings as follows:

Hypothesis: Corporate tax avoidance has a positive effect on corporate cash holdings.

\section{Model and Variables}

Based on previous investigations, the research examines the impact of corporate tax avoidance on cash holdings. In addition, control variables suitable for the Vietnamese context are also considered in the model.

\subsection{Model}

This section focuses on developing a regression model that examines the impacts of tax avoidance on corporate cash holdings. According to trade-off theory, we argue that cash 
holding can be determined by a trade-off between the cost and benefits of having liquid assets to achieve optimal cash, like as predicted by the model developed by Chang-Soo Kim, David C. Mauer, and Ann E. Sherman (1998). Accordingly, if a company deviates from the optimal cash level, it will adjust to return to that level in subsequent periods and be measured by a partial adjustment model. Typically, the firm's cash holdings may be high or lower than the target, and will gradually adjust to the target cash holdings.

$$
\operatorname{Cash}_{i, t}-\operatorname{Cash}_{i, t-1}=\alpha\left(\operatorname{Cash}_{i, t}^{*}-\operatorname{Cash}_{i, t-1}\right) .
$$

In which, $\operatorname{Cash}_{i, t}$ and $\operatorname{Cash}_{i, t-1}$ are real cash holdings of firm i in t and t-1; $\operatorname{Cash}_{i, t}{ }$ is optimal cash holdings and $\alpha$ is adjusted coefficient. From Equation (1), we have

$$
\operatorname{Cash}_{i, t}=\alpha \operatorname{Cash}_{i, t}^{*}+(1-\alpha) \operatorname{Cash}_{i, t-1}
$$

According to Equation (2), if $\alpha$ receives 1 value it means $\operatorname{Cash}_{i, t}$ equals $\operatorname{Cash}_{i, t}{ }$. It implies firms has adjusted cash holdings to toward target cash holdings. Otherwise, $\alpha$ equals 0 , it means the firms do not have any adjustment for optimal cash holdings. Thus, we have dynamic models with (2), where $\delta=1-\alpha$ :

$$
C A S H_{i t}=\delta_{0}+\delta_{1} C A S H_{i t-1}+\delta_{2} C T A_{i t}+\delta_{3} L E V_{i t}+\delta_{4} C F O_{i t}+\delta_{5} S I Z E_{i t}+\delta_{6} P P E_{i t}+\delta_{7} G R O W T H_{i t}+\varepsilon_{i t}
$$

In Equation (3), we have dynamic models with the lag of the dependent variable. Thus, it exactly causes endogenous problems in estimations due to the correlation between the dependent variable and independent variables. Therefore, to solve the technical aspects of the empirical model, we use generalized two-step regression method (two-step sys-GMM) to solve the heterogeneity, and sequence correlation of the model due to the influence of endogenous technology factor. Furthermore, the two-step sys-GMM system is more efficient than one-step GMM due to the use of the optimal sub-weight matrix ((Blundell, Bond, \& Windmeijer, 2000)). Hansen test of override restrictions is used for the robustness of GMM estimation model; while the Arellano-Bond test AR (2) shows the autocorrelation for all level (Roodman, 2009), ensuring free error-terms in residual.

\subsection{A measure of corporate tax avoidance}

There are three measurements of corporate tax avoidance $(C T A)$. Both the first and second measures begin at the view corporate tax avoidance consider as firm's tax burden (Dyreng, Hanlon, \& Maydew, 2008). Two measures are based on effective tax rate (ETR include current effective tax rate (Current ETR) and cash effective tax rate (Cash ETR)) (Salihu, Obid, \& Annuar, 2013; Wu, Wu, Zhou, \& Wu, 2012).

The first measurement : According to Cheng et al. (2012), Current ETR is account by:

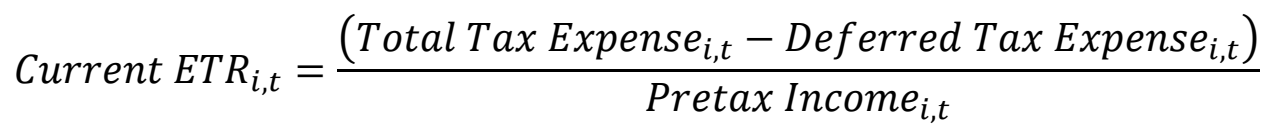

Current ETR is a reversed role of corporate tax avoidance, as lower rates of efficient tax rate mention a higher engagement in tax aggressive (M. M. Frank et al., 2009).

The second measurement: According to prior literature (Cheng, Huang, Li, \& Stanfield, 2012; Dyreng et al., 2008; Dyreng, Hanlon, \& Maydew, 2010; McGuire, Wang, \& Wilson, 2014), Cash ETR, is is account by : 


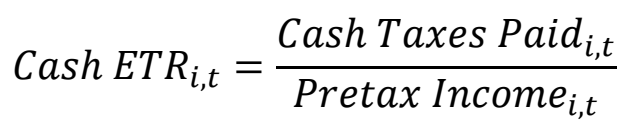

Cash ETR applies data mainly from the cash flow statement, which accommodates to attend at cash-based aspects. This is an advantage when inspected in terms of being unaffected by the accrual basis resulting in the restricted lead to restrain earnings management (X. Chen, Hu, Wang, \& Tang, 2014). Consistent with preceding paper, we limit Current ETR to transgression in the interval $[0,1]$.

The third measurement: Book-Tax Difference $(B T D)$ is a method of measuring the difference between accounting and taxation, which is regularly employed in the CTA variable (Lin, Tong, \& Tucker, 2014; Wilson, 2009). We measure BTD by pre-tax income minus taxable income divided by total assets. When the business utilizes high tax avoidance behavior corresponding to the high temporary difference.

We obtain discretionary accruals, $D A_{i, t}$ for each firm i in each year t, following Kothari, Leone, and Wasley (2005). The discretionary accruals (DA) are calculated as the residuals from:

$$
\begin{gathered}
\frac{T A C_{i, t}}{A_{i, t-1}}=\beta_{1} \frac{1}{A_{i, t-1}}+\beta_{2} \frac{\Delta\left(R E V_{i, t}-A R_{i, t}\right)}{A_{i, t-1}}+\beta_{3} \frac{P P E_{i, t}}{A_{i, t-1}}+\beta_{4} \frac{R O A_{i, t}}{A_{i, t-1}}+\varepsilon_{i, t} \\
D A_{i, t}=T A C_{i, t}-N D A_{i, t}
\end{gathered}
$$

Where: $T A C$ : total accruals, $D A$ : discretionary accruals, $N D A_{i, t}$ : Non discretionary accruals for firm $\mathrm{i}$ in year $\mathrm{t}, A t-1$ : Total assets for firm $\mathrm{j}$ in year $\mathrm{t}-1, \Delta R E V_{i, t}$ : Change in the revenues (sales) for firm $\mathrm{i}$ in year $\mathrm{t}$ less revenue in year $\mathrm{t}-1, \Delta A R_{i, t}$ : Change in accounts receivables for firm $\mathrm{i}$ in year $\mathrm{t}$ less receivable in year $\mathrm{t}-1, P P E_{i, t}$ : Gross properties, plants, and equipment for firm $\mathrm{i}$ in year $\mathrm{t}, R O A_{i, t}$ is the net income of firm $\mathrm{i}$ in year $\mathrm{t}$ scaled by the lagged total assets, $\beta_{1}, \beta_{2}, \beta_{3}, \beta_{4}$ are firm specific parameters.

Because of the third measure, measuring the degree of tax avoidance on the basis of accrual should examine the degree of explanation of the representative variable of earnings management. The residual of the equation will be calculated to describe tax avoidance behaviour.

$$
B T D_{i, t}=\beta_{1} D A_{i, t}+u_{j}+e_{i, t}
$$

where $B T D_{i, t}$ is the book-tax difference for firm $\mathrm{i}$ in year $\mathrm{t}$ divided by total assets; $D A_{i, t}$ depicts the discretionary accruals for firm $i$ in year $t$ divided by total assets; $u_{j}$ is mean value of the residual for firm i over 2010-2016 period; and $e_{i, t}$ is the deviation from the mean residual uj of firm $\mathrm{i}$ in year $t$. This can be explained as a tax avoidance measure. We indicate this measure as the $C T A$ :

$$
C T A_{i, t}=u_{j}+e_{i, t}
$$

Dependent variable: $\mathrm{CASH}$ is a proxy for corporate cash holdings. Cash holdings determined by total cash and short-term investment divided total asset (Afza \& Adnan, 2007; Al-Najjar, 2013; Al-Najjar \& Clark, 2017).

Control variables: We argue that optimal cash holdings is also an equation which is depended on determinants. Several recent studies present results on cash holdings speed of adjustment for United State' firms ((Thomas W. Bates, Chang, \& Chi, 2018); (A. K. Dittmar \& Duchin, 2010); Gao (Gao, Harford, \& Li, 2013)). These studies highlight that optimal cash 
holdings varies with firm characteristics. Thus, we add some control variables in the research model to discuss the influences on the cash holdings from firm characteristics.

When companies employ high leverage, firm encounter high financial risks. Therefore, companies require liquid assets to cope with these risks. This means that companies need to maintain more cash or cash equivalents as a soft buffer to prove their credit capacity (Opler et al., 1999; Ozkan \& Ozkan, 2004). LEV is a measure of leverage level, $L E V$ is a measure of leverage level, which is calculated by the ratio of debt to total assets at year-end (Han \& Qiu, 2007; Hardin, Highfield, Hill, \& Kelly, 2009; C.-S. Kim et al., 1998; Lee \& Song, 2007).

Because the volatility of operaring cash flow $(C F O)$ is strongly related to the volatility of profit and causes future risks. In order to minimize the impression of risk, companies conduct to maintain high levels of cash (Bigelli \& Sánchez-Vidal, 2012; Han \& Qiu, 2007; Opler et al., 1999; Ozkan \& Ozkan, 2004). As a result, cash flow from operating activities will be the principal cash flow to offset when liquidity risk occurs. $C F O$ is a proxy for Operating cash flow, $C F O$ is defined by cash flow divided total assets at year-end (Thomas W Bates, Kahle, \& Stulz, 2009; A. Dittmar et al., 2003a; C.-S. Kim et al., 1998; Opler et al., 1999).

Large companies meet more risks from the business. As a result, the cash funds of these companies normally remain at a level that empowers them to face unexpected surprises. SIZE is a proxy for firm size; SIZE is a proxy for firm size. In this study, it is calculated by the natural logarithm of the book value of total assets at year-end (Al-Najjar, 2013; Al-Najjar \& Clark, 2017; A. Dittmar et al., 2003a; Ferreira \& Vilela, 2004; García-Teruel et al., 2009; Gill \& Shah, 2012).

Companies with large fixed assets will simply mortgage their assets for debt financing plans and dispense with the risk. Therefore, the larger the value of fixed assets, the company tends to need fewer cash reserves (Drobetz \& Grüninger, 2007). PPE is a proxy for the tangible asset; $P P E$ is defined by tangible asset divided total assets at year-end (A. Dittmar et al., 2003a; Drobetz \& Grüninger, 2007).

Companies invest large amounts of money in core business areas, the firm will face the risks awake. Therefore, it is necessary to hold more cash to deal with these incidents (Thomas W Bates et al., 2009; Ferreira \& Vilela, 2004; C.-S. Kim et al., 1998; Lee \& Song, 2007; Opler et al., 1999). GROWTH is the proxy for firm growth; GROWTH is calculated by the ratio of revenue year-end minus revenue previous year and revenue previous year (AlNajjar, 2013; Drobetz \& Grüninger, 2007; Gill \& Shah, 2012; Han \& Qiu, 2007).

$\varepsilon_{\mathrm{i}, \mathrm{t}}:$ error term.

$\delta_{1} \rightarrow \delta_{6}$ : Slope coefficients representing the influence of the associated independent variable on the dependent variable.

\section{Results and discussion}

We use a sample from firms listed on the Ho Chi Minh City Stock exchange and the Ha Noi Stock exchange from 2010 to 2016. The first stock exchange in Ho Chi Minh City (HOSE) was established in 2000. Then, the Hanoi Stock Exchange (HNX) was launched in 2005. According to the State Security Commission of Vietnam, there are 726 listed firms on both stock exchange (HOSE: 342, HNX: 384) on November 30th, 2017. Although the number of listed firms are not large in comparison to total corporate on Vietnam economy, they are assumed to follow agency theory.

The research uses secondary data to measure concepts in the model. All data was collected from financial statements of listed companies, collected from the data stream of Thomson Reuters EIKON at financial market simulation room - University of Economics and 
Law. Through data collection, the elimination of missing data, incomplete data to calculate corporate tax avoidance variables. The survey sample of 125 companies in the period from 2010 to 2016, all 875 observations were used for the analysis.

We do not choose banks, security companies, insurance companies, and financial companies in our data sample according to previous studies (Gaaya et al., 2017; Yorke, Amidu, \& Agyemin-Boateng, 2016). Moreover, Financial firms have business characteristics, comply with other regulations, and the difference with the rest of the companies. (Jiraporn, Kim, \& Davidson, 2008; King \& Santor, 2008).

Descriptive statistics of variables is provided in Table 1.

The mean value of $B T D$ of sample firms is 0.3701 , which is higher than -0.0009 in China (X. Chen et al., 2014) and -0.008 in Korea (Lim, 2011). The standard deviation of BTD is 0.3165 , which is higher than 0.104 in China (X. Chen et al., 2014) and 0.077 in Korea (Lim, 2011). These figures mean that in the Vietnamese context the accumulated BTD is positively opposed to China and Korea data.

Table 1. Descriptive of variables

\begin{tabular}{lccccc}
\hline VARIABLE & OBSERVATIONS & MEAN & SD & MINIMUM & MAXIMUM \\
\hline CASH & 875 & 0.143 & 0.1322 & 0.0025 & 0.7687 \\
\hline CURRENTETR & 875 & 0.219 & 0.3073 & - & 1.0000 \\
\hline CASHETR & 875 & 0.154 & 0.1952 & - & 0.9711 \\
\hline BTD & 875 & 0.370 & 0.3165 & 0.0000 & 0.9997 \\
\hline LEV & 875 & 0.559 & 0.1939 & 0.0404 & 0.9345 \\
\hline CFO & 875 & 0.050 & 0.1205 & $(0.6959)$ & 1.1893 \\
\hline SIZE & 875 & 28.097 & 1.4309 & 24.6898 & 32.8265 \\
\hline PPE & 875 & 0.245 & 0.1945 & 0.0007 & 0.8838 \\
\hline GROWTH & 875 & 1.907 & 16.8718 & $(0.9972)$ & 328.8970 \\
\hline
\end{tabular}

Notes: The table reports summary statistics of variables over the period from 2010 to 2016 for Vietnamese listed firms. CASH is the cash holding indicator, calculated as total cash and short-term investment divided total asset. Current ETR is computed as the ratio of total tax expense minus deferred tax expense over pretax income. Cash ETR is calculated as the ratio of cash taxes paid over pretax income. BTD is Book-tax difference. LEV is firm leverage, measured as the ratio of total debt over total assets. CFO is net operating cash flow and total assets. SIZE is firm size, that is, natural log of assets. PPE is the ratio of net plant, property, and equipment to total assets. GROWTH is sale growth rate.

Table 2 displays a correlation matrix among variables employed in the paper. The relationships between the study variables were not significantly correlated with 0.8 , so no multicollinearity occurred (Gujarati \& Porter, 2003). Cash holding is negatively correlated with CURRENTETR, BTD, firm leverage, tangible assets, firm growth and positively correlated with CASHETR, firm size, operating cash flow. 
RECENT ISSUES IN ECONOMIC DEVELOPMENT

Table 2. Pearson correlation coefficient matrix

\begin{tabular}{|c|c|c|c|c|c|c|c|c|c|}
\hline & CASH & CURRENTETR & CASHETR & BTD & LEV & CFO & SIZE & PPE & GROWTH \\
\hline $\mathrm{CASH}$ & 1 & & & & & & & & \\
\hline CURRENTETR & -0.1058 & 1 & & & & & & & \\
\hline CASHETR & 0.2056 & -0.211 & 1 & & & & & & \\
\hline BTD & -0.0619 & 0.0256 & 0.0573 & 1 & & & & & \\
\hline LEV & -0.3407 & 0.0156 & -0.0716 & 0.1432 & 1 & & & & \\
\hline $\mathrm{CFO}$ & 0.3054 & -0.1031 & 0.0872 & -0.1174 & -0.2386 & 1 & & & \\
\hline SIZE & 0.0593 & -0.0281 & 0.1591 & 0.0361 & 0.1857 & -0.0131 & 1 & & \\
\hline PPE & -0.2173 & -0.0215 & -0.0107 & 0.0221 & -0.0359 & 0.2331 & 0.1205 & 1 & \\
\hline GROWTH & -0.0072 & -0.0484 & 0.0963 & -0.0144 & 0.0313 & -0.02 & 0.0694 & 0.007 & 1 \\
\hline
\end{tabular}

Notes: The table reports the correlation matrix over the period from 2010 to 2016 for Vietnamese listed firms. CASH is the cash holding indicator, calculated as total cash and short-term investment divided total asset. Current ETR is computed as the ratio of total tax expense minus deferred tax expense over pretax income. Cash ETR is calculated as the ratio of cash taxes paid over pretax income. BTD is Book-tax difference. LEV is firm leverage, measured as the ratio of total debt over total assets. CFO is net operating cash flow and total assets. SIZE is firm size, that is, natural log of assets. PPE is the ratio of net plant, property, and equipment to total assets. GROWTH is sale growth rate.

Table 3. Regression results with Current ETR

\begin{tabular}{lcccccc}
\hline \multicolumn{1}{c}{ Variables } & Coefficient & Standard error & $\mathbf{t}$ & P-value & [95\% Conf. & Interval] \\
\hline Lag of Dep. Var & $0.3152^{* *}$ & 0.1556 & 2.02 & 0.043 & 0.00950 & 0.6209 \\
\hline CURRENTETR & $0.0571^{* *}$ & 0.0291 & 1.96 & 0.05 & -0.0001 & 0.1143 \\
\hline LEV & 0.0057 & 0.3218 & 0.02 & 0.986 & -0.6263 & 0.6377 \\
\hline CFO & 0.0600 & 0.0646 & 0.93 & 0.354 & -0.0669 & 0.1870 \\
\hline SIZE & $0.0710^{* * *}$ & 0.0237 & 2.99 & 0.003 & 0.0244 & 0.1177 \\
\hline PPE & -0.2223 & 0.2833 & -0.78 & 0.433 & -0.778 & 0.3341 \\
\hline GROWTH & 0.0012 & 0.0053 & 0.24 & 0.812 & -0.0092 & 0.0117 \\
\hline J- statistic & & \multicolumn{7}{c}{21.07} & & \\
\hline Prob J- statistic & & & 0.223 & & \\
\hline
\end{tabular}

$*, * *, * * *$ denotes the level of significance of $10 \% ; 5 \%$ and $1 \%$ respectively.

Table 4. Regression results with Cash ETR

\begin{tabular}{lcccccc}
\hline \multicolumn{1}{c}{ Variables } & Coefficient & $\begin{array}{c}\text { Standard } \\
\text { error }\end{array}$ & $\mathbf{t}$ & P-value & [95\% Conf. & Interval] \\
\hline Lag of Dep. Var & $0.2607^{*}$ & 0.1484 & 1.76 & 0.079 & -0.0307 & 0.5521 \\
\hline CASHETR & $0.1597^{*}$ & 0.0868 & 1.84 & 0.066 & -0.0108 & 0.3301 \\
\hline LEV & -0.0964 & 0.3964 & -0.24 & 0.808 & -0.8748 & 0.6820 \\
\hline CFO & 0.1042 & 0.0665 & 1.57 & 0.118 & -0.0264 & 0.2348 \\
\hline SIZE & $0.0474^{*}$ & 0.0252 & 1.88 & 0.06 & -0.0020 & 0.0968 \\
\hline PPE & $-0.7484^{* * *}$ & 0.2728 & -2.74 & 0.006 & -1.2841 & -0.2126 \\
\hline GROWTH & 0.0017 & 0.0077 & 0.22 & 0.825 & -0.0133 & 0.0167 \\
\hline J- statistic & & 31.36 & & & \\
\hline Prob J- statistic & & 0.051 & & & \\
\hline
\end{tabular}

$*, * * * * *$ denotes the level of significance of $10 \% ; 5 \%$ and $1 \%$ respectively. 
RECENT ISSUES IN ECONOMIC DEVELOPMENT

Table 5. Regression results with BTD

\begin{tabular}{lcccccc}
\hline \multicolumn{1}{c}{ Variables } & Coefficient & Standard error & $\mathbf{t}$ & P-value & $\begin{array}{l}\text { [95\% } \\
\text { Conf. }\end{array}$ & Interval] \\
\hline Lag of Dep. Var & $0.6486^{* *}$ & 0.2567 & 2.53 & 0.012 & 0.1444 & 1.1528 \\
\hline BTD & $0.2338^{*}$ & 0.1355 & 1.73 & 0.085 & -0.0323 & 0.4998 \\
\hline LEV & 0.1498 & 0.5401 & 0.28 & 0.782 & -0.9109 & 1.2105 \\
\hline CFO & $0.1601^{*}$ & 0.0920 & 1.74 & 0.082 & -0.0206 & 0.3407 \\
\hline SIZE & 0.0047 & 0.0383 & 0.12 & 0.902 & -0.0705 & 0.0799 \\
\hline PPE & $-1.0986^{* *}$ & 0.4920 & -2.23 & 0.026 & -2.0648 & -0.1324 \\
\hline GROWTH & -0.0021 & 0.0092 & -0.23 & 0.816 & -0.0202 & 0.0159 \\
\hline J- statistic & & 8.02 & & & \\
\hline Prob J- the statistic & & 0.532 & & & \\
\hline
\end{tabular}

$*, * * * * *$ denotes the level of significance of $10 \% ; 5 \%$ and $1 \%$ respectively;

Table 3,4,5 manifests the regression outcomes on the connection between tax aggressive and cash holdings. Columns coefficient tabulate the regression outcomes using CURRENTETR, CASHETR, and BTD as independent variables, respectively. The results explicate that corporate tax avoidance has a positive influence on cash holdings through all three corporate tax avoidance measures, at a significance level of 5\% and $10 \%$. This means that the company is more aggressive in avoiding tax evasion, the higher the level of cash holdings. Furthermore, the magnitude of the coefficients implies that cash holdings stretch by 0.2338 when the book-tax difference level gains by one standard deviation (0.1355).

The results demonstrate that corporate tax avoidance has a positive effect on cash holdings, consistent with findings in M. Z. Frank and Goyal (2014), Di and Hanke (2013) during bad times. On this sample, corporate tax avoidance really enhances shareholder benefit consistent with ((Armstrong et al., 2015; Mihir A Desai \& Dharmapala, 2009; Hanlon \& Heitzman, 2010; Wilson, 2009). This lead to improving cash holdings following Foley, Hartzell, Titman, and Twite (2007); Hanlon, Maydew, and Saavedra (2017).

Research results designate that corporate tax avoidance can reduce the transparency of financial reporting information due to accounting estimate to avoid tax (Balakrishnan, Blouin, \& Guay, 2011). In addition, the complexity of internal transactions also harms the reputation of the company (Bauweraerts \& Vandernoot, 2013; S. Chen et al., 2010; Mihir A Desai, Dyck, \& Zingales, 2007). Nevertheless, investors respond positively to companies with high cash reserves to counter market risks and diversify their investment portfolio (Chan, Lin, \& Mo, 2010; Mills, 1998).

With control variables, Operating cash flow has a positive effect on Cash holdings. This indicates that companies hold high cash positions to avoid bankruptcy risks (Bigelli \& Sánchez-Vidal, 2012; Han \& Qiu, 2007; Opler et al., 1999; Ozkan \& Ozkan, 2004). In contrast to the sample of energy companies in the Vietnamese market (Thu \& Khuong, 2018). The larger the size of the company, the more cash it requires to hold to guarantee the ability to repay the debt and diversify the portfolio (Ozkan \& Ozkan, 2004). The company demands collateral to increase loans, in which tangible assets are a credit that is always prioritized. Therefore, when a company has a large tangible asset value, it tends to hold low cash (Drobetz \& Grüninger, 2007). 


\section{Conclusion}

The purpose of this research is to investigate the effect of corporate tax avoidance on cash holdings in the Vietnamese context. Based on a sample of 125 Vietnamese listed firms over the period from 2010 to 2016, we find that the relationship between corporate tax avoidance and cash holdings is positive. According to Mihir A Desai and Dharmapala (2009), there is much research on developing countries to get multi-view on corporate tax avoidance. This research support shareholders, managers, third party, and government get information on corporate tax avoidance in developing market like Vietnam.

According to Fresard (2010), the company has the greater the cash reserves are able to compete and dominate the market. Consequently, managers frequently need to apply tax avoidance to reduce their tax expenditures for the purpose of increasing their competitiveness. This is meaningful to both managers and shareholders for personal gain.

The limitation of our investigation is that we concentrate on corporate tax avoidance to non-financial firms in the Vietnamese context, and we do not have variables represent the specific institutional environment. Further research can compare the differences relations tax avoidance on cash holdings in Vietnam to other ASEAN countries (Kurniawan \& Nuryanah, 2017). Furthermore, continuous research can focus on financial firms to exam their relationship.

\section{Acknowledgement}

This research is funded by University of Economics and Law, Vietnam National University Ho Chi Minh City, Vietnam.

\section{References}

Afza, T., \& Adnan, S. (2007). Determinants of corporate cash holdings: A case study of Pakistan. Paper presented at the Proceedings of Singapore Economic Review Conference (SERC).

Al-Najjar, B. (2013). The financial determinants of corporate cash holdings: Evidence from some emerging markets. International business review, 22(1), 77-88.

Al-Najjar, B., \& Clark, E. (2017). Corporate governance and cash holdings in MENA: Evidence from internal and external governance practices. Research in International Business and Finance, 39, 1-12.

Armstrong, C. S., Blouin, J. L., Jagolinzer, A. D., \& Larcker, D. F. (2015). Corporate governance, incentives, and tax avoidance. Journal of Accounting and Economics, $60(1), 1-17$.

Ayers, B. C., Jiang, J. X., \& Laplante, S. K. (2009). Taxable income as a performance measure: The effects of tax planning and earnings quality. Contemporary Accounting Research, 26(1), 15-54.

Balakrishnan, K., Blouin, J., \& Guay, W. (2011). Does tax aggressiveness reduce financial reporting transparency. Unpublished manuscript. University of Pennsylvania, Philadelphia, PA.

Bates, T. W., Chang, C. H., \& Chi, J. D. (2018). Why has the value of cash increased over time? Journal of Financial and Quantitative Analysis, 53(2), 749-787.

Bates, T. W., Kahle, K. M., \& Stulz, R. M. (2009). Why do US firms hold so much more cash than they used to? The journal of finance, 64(5), 1985-2021. 
Bauweraerts, J., \& Vandernoot, J. (2013). Are family firms more tax aggressive than nonfamily firms? Empirical evidence from Belgium. International Journal of Management, 30(4), 235.

Bigelli, M., \& Sánchez-Vidal, J. (2012). Cash holdings in private firms. Journal of Banking \& Finance, 36(1), 26-35. doi:10.1016/j.jbankfin.2011.06.004

Blundell, R., Bond, S., \& Windmeijer, F. (2000). Estimation in dynamic panel data models: improving on the performance of the standard GMM estimator. Advances in Econometrics. JAI Press, Elsevier Science, Amsterdam, 15.

Bushman, R. M., \& Smith, A. J. (2001). Financial accounting information and corporate governance. Journal of Accounting and Economics, 32(1-3), 237-333.

Chan, K. H., Lin, K. Z., \& Mo, P. L. (2010). Will a departure from tax-based accounting encourage tax noncompliance? Archival evidence from a transition economy. Journal of Accounting and Economics, 50(1), 58-73.

Chen, S., Chen, X., Cheng, Q., \& Shevlin, T. (2010). Are family firms more tax aggressive than non-family firms? Journal of Financial Economics, 95(1), 41-61. doi:10.1016/j.jfineco.2009.02.003

Chen, X., Hu, N., Wang, X., \& Tang, X. (2014). Tax avoidance and firm value: evidence from China. Nankai Business Review International, 5(1), 25-42.

Chen, Y., Huang, S., Pereira, R., \& Wang, J. (2011). Corporate tax avoidance and firm opacity. Unpublished Working Paper University of Missouri.

Cheng, C. A., Huang, H. H., Li, Y., \& Stanfield, J. (2012). The effect of hedge fund activism on corporate tax avoidance. The Accounting Review, 87(5), 1493-1526.

Desai, M. A., \& Dharmapala, D. (2006). Corporate tax avoidance and high-powered incentives. Journal of Financial Economics, 79(1), 145-179. doi:10.1016/j.jfineco.2005.02.002

Desai, M. A., \& Dharmapala, D. (2008). Tax and corporate governance: an economic approach Tax and corporate governance (pp. 13-30): Springer.

Desai, M. A., \& Dharmapala, D. (2009). Corporate tax avoidance and firm value. The review of Economics and Statistics, 91(3), 537-546.

Desai, M. A., Dyck, A., \& Zingales, L. (2007). Theft and taxes. Journal of Financial Economics, 84(3), 591-623.

Dhaliwal, D. S., Huang, S. X., Moser, W. J., \& Pereira, R. (2011). Corporate tax avoidance and the level and valuation of firm cash holdings.

Di, H., \& Hanke, S. A. (2013). The impact of double taxation on small firms' cash holdings. Applied Financial Economics, 23(16), 1349-1359.

Dittmar, A., Mahrt-Smith, J., \& Servaes, H. (2003a). International corporate governance and corporate cash holdings. Journal of financial and quantitative analysis, 38(1), 111133.

Dittmar, A., Mahrt-Smith, J., \& Servaes, H. (2003b). International Corporate Governance and Corporate Cash Holdings. The Journal of Financial and Quantitative Analysis, 38(1), 111. doi: $10.2307 / 4126766$

Dittmar, A. K., \& Duchin, R. (2010). The Dynamics of Cash. SSRN Electronic Journal. doi:10.2139/ssrn.1569529

Drobetz, W., \& Grüninger, M. C. (2007). Corporate cash holdings: Evidence from Switzerland. Financial Markets and Portfolio Management, 21(3), 293-324. doi:10.1007/s11408-007-0052-8

Dyreng, S. D., Hanlon, M., \& Maydew, E. L. (2008). Long-run corporate tax avoidance. The Accounting Review, 83(1), 61-82.

Dyreng, S. D., Hanlon, M., \& Maydew, E. L. (2010). The effects of executives on corporate tax avoidance. The Accounting Review, 85(4), 1163-1189. 
Faulkender, M., \& Wang, R. (2006). Corporate Financial Policy and the Value of Cash. The Journal of Finance, 61(4), 1957-1990. doi:10.1111/j.1540-6261.2006.00894.x

Ferreira, M. A., \& Vilela, A. S. (2004). Why do firms hold cash? Evidence from EMU countries. European Financial Management, 10(2), 295-319.

Foley, C. F., Hartzell, J. C., Titman, S., \& Twite, G. (2007). Why do firms hold so much cash? A tax-based explanation. Journal of Financial Economics, 86(3), 579-607.

Frank, M. M., Lynch, L. J., \& Rego, S. O. (2009). Tax reporting aggressiveness and its relation to aggressive financial reporting. The Accounting Review, 84(2), 467-496.

Frank, M. Z., \& Goyal, V. K. (2014). The profits-leverage puzzle revisited. Review of Finance, 19(4), 1415-1453.

Fresard, L. (2010). Financial strength and product market behavior: The real effects of corporate cash holdings. The journal of finance, 65(3), 1097-1122.

Gaaya, S., Gaaya, S., Lakhal, N., Lakhal, N., Lakhal, F., \& Lakhal, F. (2017). Does family ownership reduce corporate tax avoidance? The moderating effect of audit quality. Managerial Auditing Journal, 32(7), 731-744.

Gao, H., Harford, J., \& Li, K. (2013). Determinants of corporate cash policy: Insights from private firms. Journal of Financial Economics, 109(3), 623-639. doi:10.1016/j.jfineco.2013.04.008

García-Teruel, P. J., Martínez-Solano, P., \& Sánchez-Ballesta, J. P. (2009). Accruals quality and corporate cash holdings. Accounting \& Finance, 49(1), 95-115.

Gill, A., \& Shah, C. (2012). Determinants of corporate cash holdings: Evidence from Canada. International Journal of Economics and Finance, 4(1), 70.

Gujarati, D., \& Porter, D. (2003). Multicollinearity: What happens if the regressors are correlated. Basic econometrics, 363.

Hai, B. X., \& Nunoi, C. (2008). Corporate governance in Vietnam: A system in transition. Hitotsubashi journal of commerce and management, 42 (1 (42), 45-65.

Han, S., \& Qiu, J. (2007). Corporate precautionary cash holdings. Journal of corporate finance, 13(1), 43-57.

Hanlon, M., \& Heitzman, S. (2010). A review of tax research. Journal of Accounting and Economics, 50(2), 127-178.

Hanlon, M., Kelley Laplante, S., \& Shevlin, T. (2005). Evidence for the possible information loss of conforming book income and taxable income. The Journal of Law and Economics, 48(2), 407-442.

Hanlon, M., Maydew, E. L., \& Saavedra, D. (2017). The taxman cometh: Does tax uncertainty affect corporate cash holdings? Review of Accounting Studies, 22(3), 1198-1228.

Hanlon, M., \& Slemrod, J. (2009). What does tax aggressiveness signal? Evidence from stock price reactions to news about tax shelter involvement. Journal of Public Economics, 93(1), 126-141.

Hardin, W. G., Highfield, M. J., Hill, M. D., \& Kelly, G. W. (2009). The determinants of REIT cash holdings. The Journal of Real Estate Finance and Economics, 39(1), 3957.

Harford, J., Mansi, S. A., \& Maxwell, W. F. (2012). Corporate governance and firm cash holdings in the US Corporate governance (pp. 107-138): Springer.

Hoang, T. C., Abeysekera, I., \& Ma, S. (2017). The Effect of Board Diversity on Earnings Quality: An Empirical Study of Listed Firms in Vietnam. Australian Accounting Review, 27(2), 146-163.

Hogan, B., \& Noga, T. (2012). The Association between Changes in Auditor Provided Tax Services and Long-Term Corporate Tax Avoidance. 
Jensen, M. C. (1986). Agency costs of free cash flow, corporate finance, and takeovers. The American economic review, 76(2), 323-329.

Jensen, M. C., \& Meckling, W. H. (1976a). Theory of the firm: Managerial behavior, agency costs and ownership structure. Journal of Financial Economics, 3(4), 305-360.

Jensen, M. C., \& Meckling, W. H. (1976b). Theory of the firm: Managerial behavior, agency costs and ownership structure. Journal of Financial Economics, 3, 305-360. doi:10.1016/0304-405X(76)90026-X

Jiraporn, P., Kim, Y. S., \& Davidson, W. N. (2008). Multiple directorships and corporate diversification. Journal of Empirical Finance, 15(3), 418-435.

Kim, C.-S., Mauer, D. C., \& Sherman, A. E. (1998). The determinants of corporate liquidity: Theory and evidence. Journal of financial and quantitative analysis, 33(3), 335-359.

Kim, J.-B., Li, Y., \& Zhang, L. (2011). Corporate tax avoidance and stock price crash risk: Firm-level analysis. Journal of Financial Economics, 100(3), 639-662.

King, M. R., \& Santor, E. (2008). Family values: Ownership structure, performance and capital structure of Canadian firms. Journal of Banking \& Finance, 32(11), 24232432.

Kothari, S. P., Leone, A. J., \& Wasley, C. E. (2005). Performance matched discretionary accrual measures. Journal of Accounting and Economics, 39(1), 163-197.

Kurniawan, M. I., \& Nuryanah, S. (2017). The Effect of Corporate Tax Avoidance on the Level of Corporate Cash Holdings: Evidence from Indonesian Public Listed Companies. Australasian Accounting, Business and Finance Journal, 11(4), 38-52.

Lee, Y., \& Song, K. (2007). Why have East Asian Firms Increased Cash Holdings so much after the Asian Financial Crisis? Paper presented at the th Australian Finance \& Banking Conference.

Lim, Y. (2011). Tax avoidance, cost of debt and shareholder activism: Evidence from Korea. Journal of Banking \& Finance, 35(2), 456-470.

Lin, S., Tong, N., \& Tucker, A. L. (2014). Corporate tax aggression and debt. Journal of Banking \& Finance, 40, 227-241.

Lisowsky, P. (2010). Seeking shelter: Empirically modeling tax shelters using financial statement information. Accounting Review, 85, 1693-1720.

Manoel, A. A. S., da Costa Moraes, M. B., Santos, D. F. L., \& Neves, M. F. (2018). Determinants of corporate cash holdings in times of crisis: insights from Brazilian sugarcane industry private firms. International Food and Agribusiness Management Review, 21(2), 201-218.

Martínez-Sola, C., García-Teruel, P. J., \& Martínez-Solano, P. (2013). Corporate cash holding and firm value. Applied Economics, 45(2), 161-170.

McGuire, S. T., Wang, D., \& Wilson, R. J. (2014). Dual class ownership and tax avoidance. The Accounting Review, 89(4), 1487-1516.

Mills, L. F. (1998). Book-tax differences and Internal Revenue Service adjustments. Journal of Accounting Research, 36(2), 343-356.

Myers, S., \& Raghuram, R. (1998). The Paradox of Liquidity. Unpublished Working Paper Center for Research in Security Prices, Graduate School of Business, University of Chicago.

Nguyen, T. T., \& Van Dijk, M. A. (2012). Corruption, growth, and governance: Private vs. state-owned firms in Vietnam. Journal of Banking \& Finance, 36(11), 2935-2948.

OECD. (2013). Addressing Base Erosion and Profit Shifting. OECD, Paris.

Ogundipe, L. O., Ogundipe, S. E., \& Ajao, S. K. (2012). Cash holding and firm characteristics: Evidence from Nigerian emerging market. Journal of Business Economics and Finance, 1(2), 45-58. 
Opler, T., Pinkowitz, L., Stulz, R., \& Williamson, R. (1999). The determinants and implications of corporate cash holdings. Journal of Financial Economics, 52(1), 3-46.

Opler, T., Pinkowitz, L., Stulz, R., \& Williamson, R. (2001). Corporate cash holdings. Journal of Applied Corporate Finance, 14(1), 55-67.

Ozkan, A., \& Ozkan, N. (2004). Corporate cash holdings: An empirical investigation of UK companies. Journal of Banking \& Finance, 28(9), 2103-2134.

Pinkowitz, L., Williamson, R., \& Stulz, R. M. (2007). Cash Holdings, Dividend Policy, and Corporate Governance: A Cross-Country Analysis. Journal of Applied Corporate Finance, 19(1), 81-87.

Roodman, D. (2009). How to do xtabond2: An introduction to difference and system GMM in Stata. The Stata Journal, 9, 86-136.

Ross, S. A. (1973). The economic theory of agency: The principal's problem. The American economic review, 63(2), 134-139.

Saddour, K. (2006). The determinants and the value of cash holdings: Evidence from French firms. Retrieved from

Salihu, I. A., Obid, S. N. S., \& Annuar, H. A. (2013). Measures of corporate tax avoidance: empirical evidence from an emerging economy. International Journal of Business and Society, 14(3), 412.

Thu, P. A., \& Khuong, N. V. (2018). Factors Effect On Corporate Cash Holdings Of The Energy Enterprises Listed On Vietnam's Stock Market. International Journal Of Energy Economics And Policy, 8(5), 29-34.

Wang, L. (2015). Tax enforcement, corporate tax aggressiveness, and cash holdings. China Finance Review International, 5(4), 339-370.

Wilson, R. J. (2009). An examination of corporate tax shelter participants. The Accounting Review, 84(3), 969-999.

Wu, W., Wu, C., Zhou, C., \& Wu, J. (2012). Political connections, tax benefits and firm performance: Evidence from China. Journal of Accounting and Public Policy, 31(3), 277-300.

Yorke, S. M., Amidu, M., \& Agyemin-Boateng, C. (2016). The effects of earnings management and corporate tax avoidance on firm value. International Journal of Management Practice, 9(2), 112-131. 